\title{
RANCANG BANGUN DATA WAREHOUSE DAN DASHBOARD REKONSILIASI PENERIMAAN NEGARA DI DITJEN PERBENDAHARAAN DENGAN QLIKVIEW
}

\author{
Sholiq, Rully Agus Hendrawan, Mukhamad Hafidz \\ Jurusan Sistem Informasi, Fakultas Teknologi Informasi, Institut Teknologi Sepuluh Nopember \\ Kampus Keputih, Sukolio Surabaya 60111 \\ Telp: (031) 5999944, Fax: (031)5964965 \\ E-mail: sholiq99@gmail.com
}

\begin{abstract}
State revenue reconciliation is control efforts over the administration of state revenues to ensure the accountability of state revenue data. Directorate General of Treasury (DJPbn) is obliged to supervise the administration of state revenues by Bank/Pos Persepsi as regulated in PMK.184 / PMK/2010 about Organisasi dan Tata Kerja Kementerian Keuangan RI. However, the results of the state revenue reconciliation still presented manually so the control is not running optimally. In this paper will explain the user needs to develope the data warehouse and the state revenue reconciliation dashboard using Business Intelligence Roadmap method and QlikView technology. With this system is expected to meet the needs of DJPBN to present the state revenues reconciliation which has large and complex data in a timely manner in various formats to ease the follow-up of transactions process to Bank/Pos Persepsi.

Abstrak

Rekonsiliasi penerimaan negara merupakan salah satu upaya pengawasan atas penatausahaan penerimaan negara dalam rangka menjamin akuntabilitas data penerimaan negara. Direktorat Jenderal Perbendaharaan (DJPbn) berkewajiban melakukan pengawasan atas penatausahaan penerimaan negara oleh Bank/Pos Persepsi. Namun, hasil rekonsiliasi masih disajikan secara manual sehingga pengawasan berupa proses tindak lanjut atas transaksi penerimaan negara tidak berjalan optimal. Pada tulisan ini akan dijelaskan kebutuhan pengguna dalam penyajian hasil rekonsiliasi penerimaan negara kemudian melakukan rancang bangun data warehouse dan dashboard yang dikembangkan dengan metode Business Intelligence Roadmap dan memanfaatkan teknologi Qlikview. Sehingga akan menghasilkan keluaran berupa dokumentasi kebutuhan, perancangan, data warehouse dan dashboard hasil rekonsiliasi penerimaan negara yang harus ditindaklanjuti oleh Bank/Pos Persepsi. Dengan adanya sistem ini, diharapkan dapat memudahkan DJPbn dalam menindaklanjuti transaksi yang berpotensi merugikan negara secara tepat waktu, akurat dan efektif.
\end{abstract}

Kata kunci: data warehouse, dashboard, rekonsiliasi penerimaan negara, DJPbn, qlikview

\section{PENDAHULUAN}

Modul Penerimaan Negara (MPN) adalah suatu sistem yang terstruktur untuk mengatur proses penerimaan, penyetoran, pengumpulan data, pencatatan, pengikhtisaran sampai dengan pelaporan yang berhubungan dengan penerimaan negara. Dalam rangka menyelenggarakan operasional MPN, Kementerian Keuangan tidak dapat berdiri sendiri untuk membuka loket penerimaan negara, sehingga diperlukan kerjasama dengan perbankan/ Bank dan Kantor Pos (Bank/Pos Persepsi) sebagai channel penerimaan negara (Direktorat Pengelolaan Kas Negara, 2009). Dalam perjalanannya, penatausahaan MPN menghadapi beberapa masalah sehingga pemerintah melalui Kementerian Keuangan bermaksud menyempurnakan sistem MPN dengan menerbitkan Perdirjen Nomor 90/PB/2011 ten- tang Rekonsiliasi Data Transaksi Penerimaan Negara pada Sistem MPN (Direktorat Jenderal Perbendaharaan, 2011) yang mengatur mekanisme rekonsiliasi transaksi penerimaan negara. Selama ini hasil rekonsiliasi penerimaan negara disajikan dalam bentuk dokumen yang dilaporkan setiap bulan untuk kemudian ditindaklanjuti oleh DJPbn kepada pihak terkait. Proses panjang yang meliputi pelaporan hasil rekonsiliasi penerimaan negara dan tindak lanjut DJPbn melalui permintaan klarifikasi kepada Bank/Pos Persepsi akan memakan waktu lama dan tidak efektif.

Oleh karena itu, diperlukan sebuah sistem yang dapat menyajikan hasil rekonsiliasi penerimaan negara yang harus ditindaklanjuti Bank/Pos Persepsi seperti status data rekonsiliasi, persentase masing-masing status data hasil rekonsiliasi, 
Sholiq, dkk., Rancang Bangun Data Warehouse dan Dashboard Rekonsiliasi Penerimaan Negara..

dan pola masing-masing status data hasil rekonsiliasi per periode waktu. Berdasarkan permasalahan di atas, maka pembuatan data warehouse dan dashboard hasil rekonsiliasi penerimaan negara ini diharapkan dapat membantu DJPbn untuk melakukan analisis singkat dan melakukan tindak lanjut hasil rekonsiliasi secara lebih cepat, akurat dan efektif.

\subsection{Modul Penerimaan Negara}

Beberapa literatur mengenai penatausahaan penerimaan negara melalui sistem MPN dapat ditemukan pada PMK Nomor 37 2007. Data warehouse merupakan teknik untuk menyediakan informasi yang dibutuhkan oleh sebuah organisasi guna mendukung keputusan baik secara operasional maupun secara strategis (Kimball Group). Salah satu teknologi data warehouse yang dapat dimanfaatkan untuk menyajikan hasil rekonsiliasi penerimaan negara agar dapat dipergunakan pada dashboard adalah Microsoft SQL Server 2008.

\subsection{Dashboard}

Tujuan penggunaan dashboard menurut Eckerson (Eckerson, 2006) adalah untuk mengukur kinerja, memonitor proses yang sedang berjalan, dan memprediksi kondisi dimasa mendatang. Salah satu teknologi yang dapat dimanfaatkan untuk membangun sebuah dashboard adalah Qlikview yang memiliki karakter in-memory analytics sehingga dapat mempresentasikan data yang dinamis, sehingga kita dapat membangun sebuah tampilan dashboard yang menampilkan data yang dapat dianalisis menjadi sebuah knowledge, dapat melakukan kostumisasi terhadap laporan yang ditampilkan serta melihat dan mengatur data apa saja yang ingin ditampilkan dan yang ingin kita analisa (Ross, 2013).

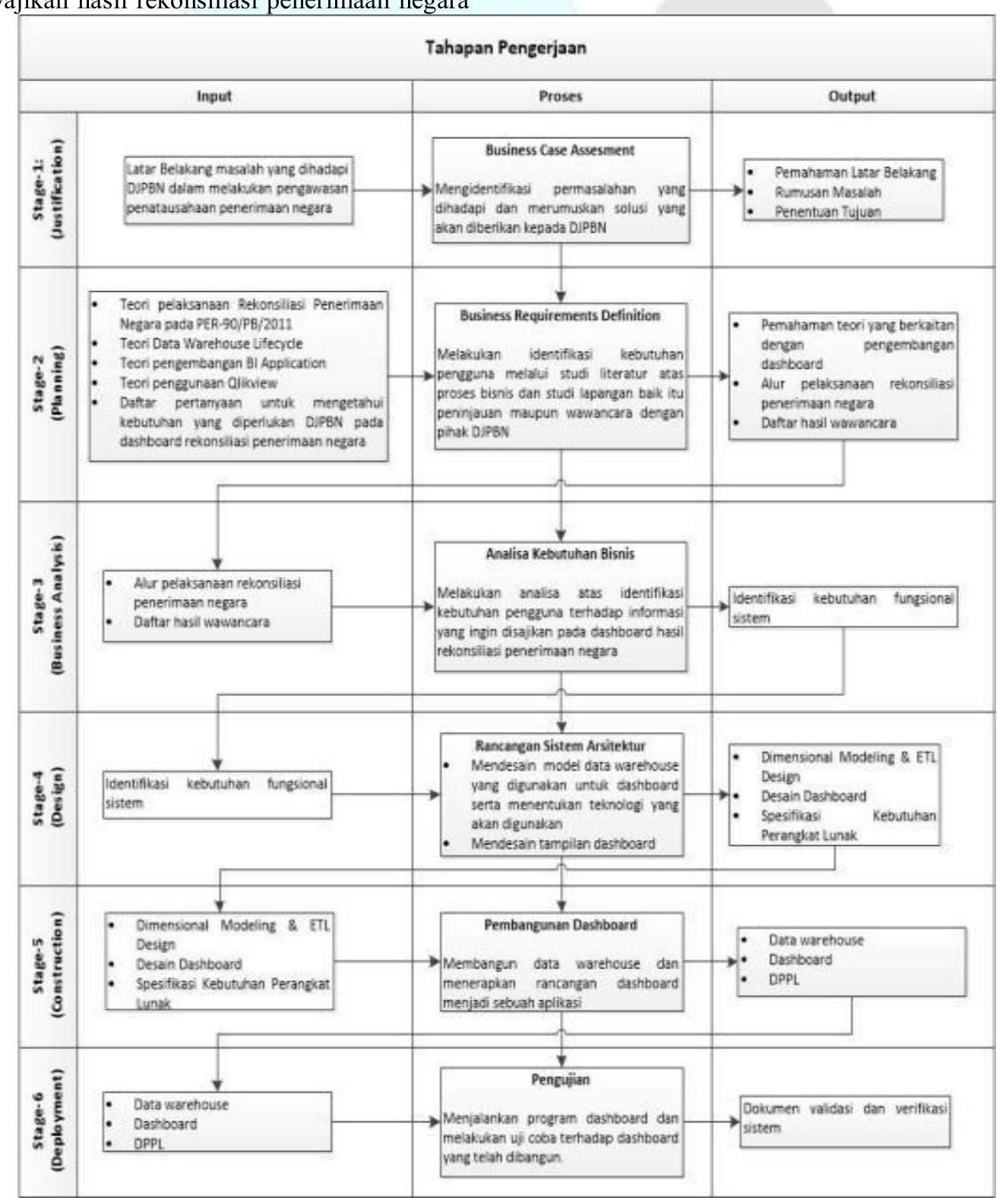

Gambar 1. Tahapan Pengerjaan 


\section{METODOLOGI}

Pengerjaan rancang bangun data warehouse dan dashboard ini mengacu pada buku Business Intelligence Roadmap (Bowles, 2010) yang terdiri dari beberapa tahapan yang akan menghasilkan beberapa luaran sebagaimana gambar 1 .

\section{HASIL dan PEMBAHASAN}

Proses analisis dimulai dengan membahas proses pengelolaan penerimaan negara melalui MPN yang dilakukan pada saat ini, identifikasi kebutuhan serta identifikasi fungsionalitas sistem. Selain itu, akan dijelaskan pula rancangan sistem arsitektur yang meliputi dimensional model dan rancangan sistem.

\subsection{Alur Pengelolaan Penerimaan Negara melalui MPN}

Secara garis besar, pengelolaan penerimaan negara melalui MPN yang dilakukan oleh DJPbn dapat diilustrasikan pada gambar di bawah ini.

\subsection{Kebutuhan Fungsional}

Berdasarkan hasil analisis kebutuhan, maka terdapat dua macam fungsionalitas sistem yang disusun berdasarkan fasilitas yang dapat diberikan oleh sistem kepada pengguna.

1. Kebutuhan fungsional bagi administrator terkait pada pengelolaan data warehouse yang memiliki fungsi-fungsi utama sebagai berikut:
a. Mengelola data KPPN
b. Mengelola data Bank
c. Mengelola tanggal
d. Mengelola data kategori rekonsiliasi MPN
e. Mengelola data grup kategori rekonsiliasi MPN
f. Mengelola data kategori rekonsiliasi LKP
g. Mengelola data fakta MPN
h. Mengelola data fakta LKP
i. Mengelola data mart

2. Sedangkan kebutuhan fungsional bagi subdit Penerimaan Negara terkait penggunaan data warehouse memiliki fungsi-fungsi utama sebagai berikut :
a. Melihat data hasil rekonsiliasi
b. Melihat data Partial Matched
c. Melihat data MPN-Unmatched
d. Melihat data Cancel-out Matched
e. Melihat data LKP-Unmatched
f. Melihat detail data Transaksi MPN
g. Menyimpan detail data Transaksi MPN
h. Menyimpan detail data LKP-Unmatched

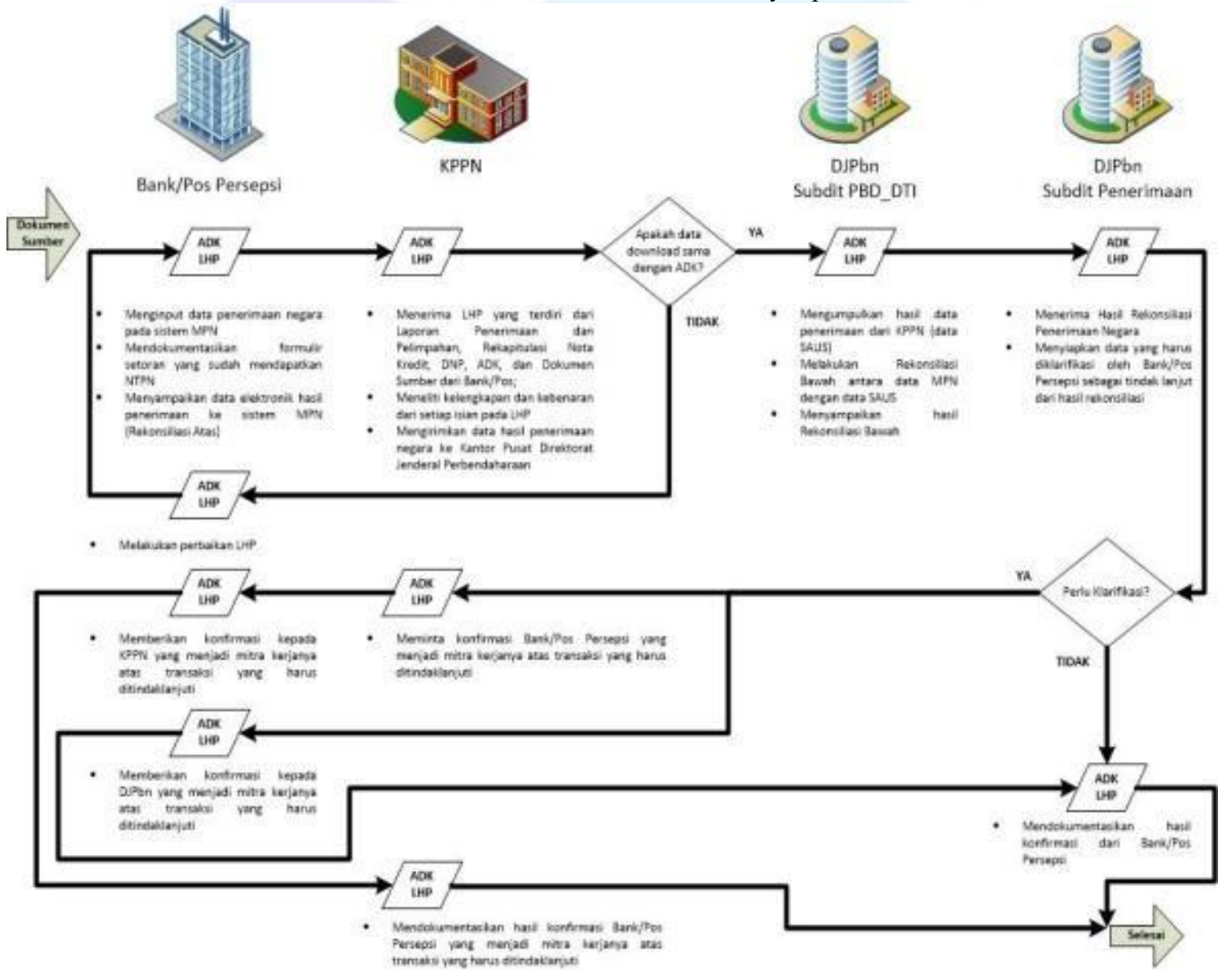

Gambar 2 Alur Pengelolaan Penerimaan Negara melalui MPN 
Sholiq, dkk., Rancang Bangun Data Warehouse dan Dashboard Rekonsiliasi Penerimaan Negara..

Kebutuhan fungsional akan dituangkan dalam bentuk diagram use case dengan menggunakan UML (Unified Modelling Language). Diagram use case akan menjadi gambaran sistem dari sudut pandang setiap aktor. Penjelasan mengenai detail fungsionalitas sistem dapat dilihat dalam dokumen Spesifikasi Kebutuhan Perangkat Lunak (SKPL).

\subsection{Rancangan Dimensional Model}

Perancangan Dimensional Model mengacu pada tahapan berikut

\section{Penentuan Proses Bisnis}

Proses bisnis yang menjadi fokus penerjaan tugas akhir ini adalah penyampaian hasil rekonsiliasi penerimaan negara berupa data penerimaan negara yang harus klarifikasi oleh Bank/Pos Persepsi.

\section{Identifikasi Grain Level}

Grain level merupakan detail data yang akan disampaikan oleh subdit Penerimaan Negara sebagai hasil rekonsiliasi penerimaan negara yang harus diklarifikasi oleh Bank/Pos Persepsi sesuai dengan PER-90/PB/2011 tentang Rekonsiliasi Data Transaksi Penerimaan Negara yang meliputi data P7, P11, Kode Bank, Kode KPPN, Tanggal Buku, kode NTB, kode NTPN, kode akun, dan nilai setor serta dan kategori hasil rekonsiliasi yang meliputi data rev flag, flsah, flrekon.

\section{Identifikasi tabel Dimensi}

Tabel dimensi yang dibutuhkan oleh sistem, yaitu:

1. Tabel dimensi Bank (DimBank)

2. Tabel dimensi KPPN (DimKppn)

3. Tabel dimensi Tanggal (DimDate)

4. Tabel dimensi Kategori Rekonsiliasi MPN (DimRekonMpn)

5. Tabel dimensi Grup Kategori Rekonsiliasi MPN (GrupRekonMpn)

6. Tabel dimensi Kategori Rekonsiliasi LKP (DimRekonLkp)

\section{Identifikasi tabel Fakta}

Tabel fakta menunjukkan detail setiap transaksi penerimaan negara yang telah direkonsiliasi. Tabel fakta yang akan dipergunakan dalam sistem, yaitu:

1. Tabel faktaMPN (FactMpn)

2. Tabel fakta LKP (FactLkp)

Berdasarkan tabel dimensi dan tabel fakta yang telah dijabarkan di atas, maka Rancangan Dimensional Model yang akan digunakan pada data warehouse hasil rekonsiliasi penerimaan negara dapat dilihat pada gambar di bawah ini.

\subsection{Perancangan Sistem}

Perancangan sistem dilakukan untuk mempersiapkan konfigurasi sistem yang akan dibangun dengan mengidentifikasi data sumber yang diperlukan, skenario ETL untuk membangun data warehouse, pemanfaatan data mart dari data OLAP hingga penyajian informasi pada dashboard.

\subsection{Konstruksi dan Pengujian}

Merupakan aktifitas membangun sistem yang telah didesain dan melakukan serangkaian pengujian untuk memastikan data warehouse dan dashboard dapat digunakan. Sebagian hal penting akan dijelaskan pada subbab di bawah ini, namun penjelasan mendetail terdapat pada dokumen Deskripsi Perancangan Perangkat Lunak (DPPL).

\subsection{Back Room (ETL Process)}

Proses Extract-Transform-Load (ETL) merupakan proses di belakang layar (back room process) yang memetakan data sumber (OLTP) ke dalam dimensional model (OLAP) berupa tabel fakta dan tabel dimensi berupa data warehouse sebagai bahan penyajian informasi pada dashboard. Hasil pemetaan tabel dari data OLTP menjadi data OLAP dapat dilihat pada tabel 1.

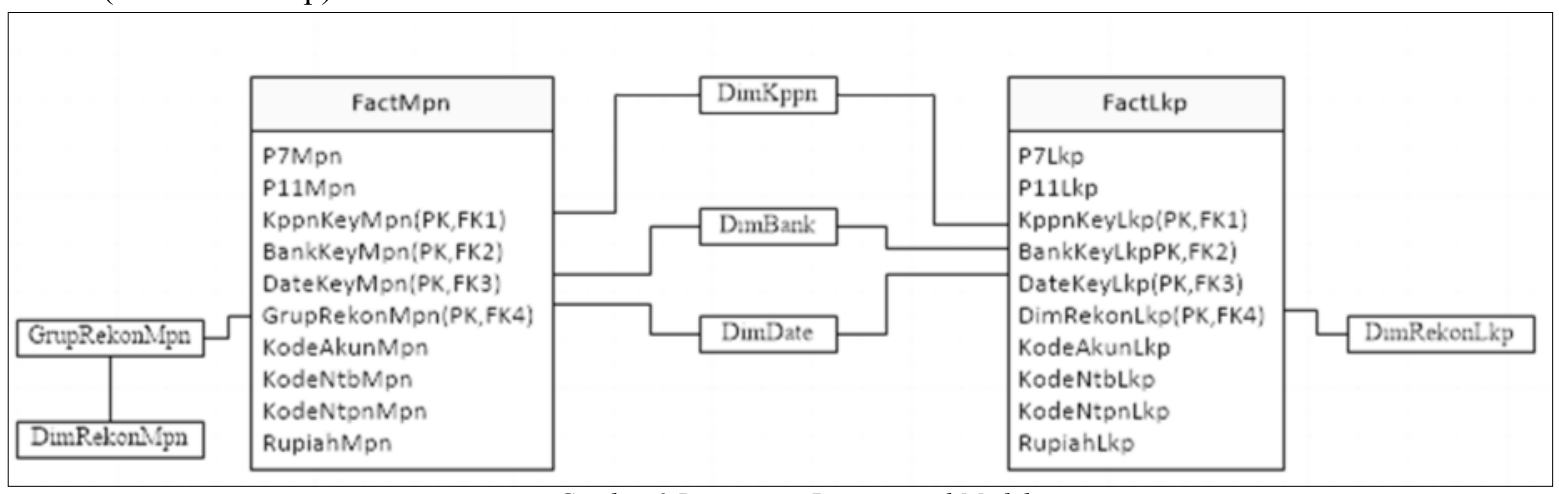

Gambar 3 Rancangan Dimensional Model 


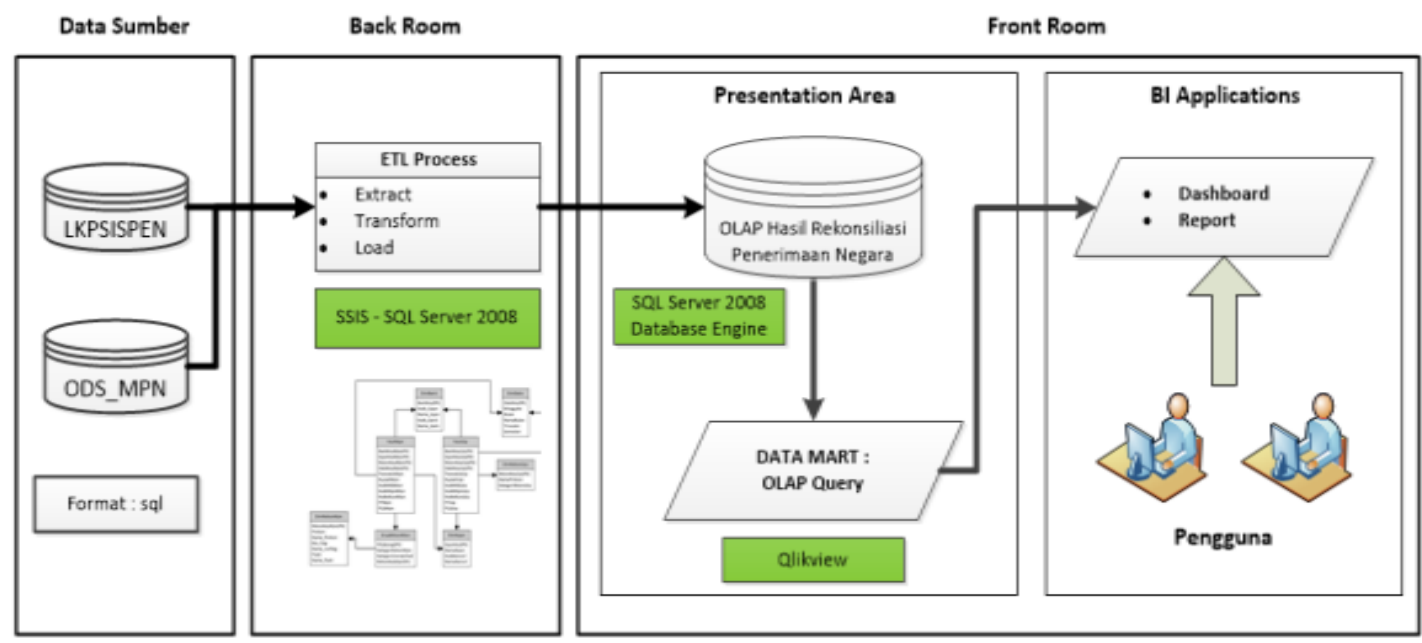

Gambar 4 Perancangan Sistem Data Warehouse dan Dashboard Rekonsiliasi Penerimaan Negara

Tabel 1. Mapping Data Sumber

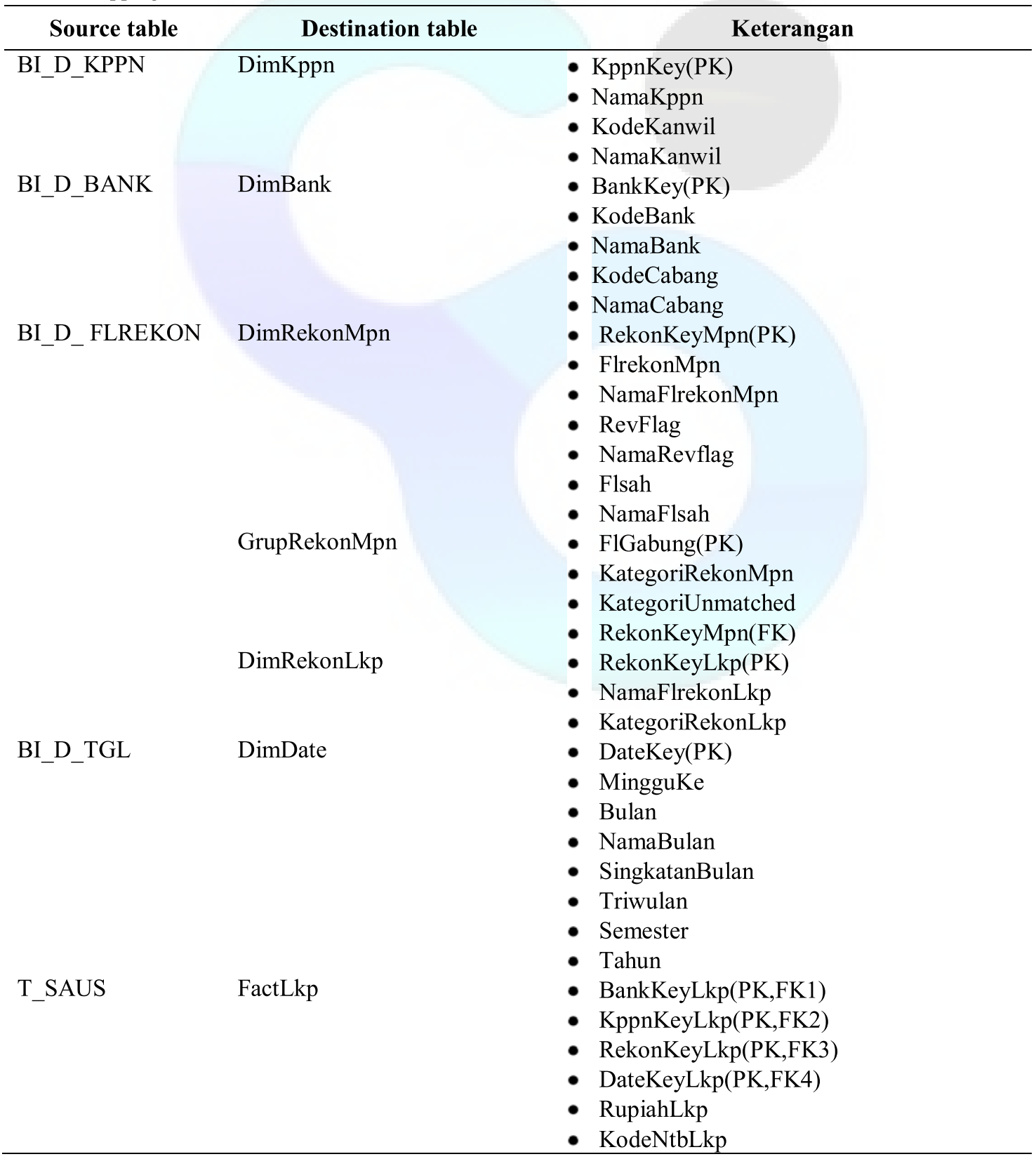


Sholiq, dkk., Rancang Bangun Data Warehouse dan Dashboard Rekonsiliasi Penerimaan Negara..

\begin{tabular}{|c|c|c|}
\hline Source table & Destination table & Keterangan \\
\hline T_MPN & FactMpn & $\begin{array}{l}\text { - KodeNtpnLkp } \\
\text { - KodeAkunLkp } \\
\text { - } \text { P7Lkp } \\
\text { - P11Lkp } \\
\text { - } \text { BankKeyMpn(PK,FK1) } \\
\text { - KppnKeyMpn(PK,FK2) } \\
\text { - RekonKeyMpn(PK,FK3) } \\
\text { - DateKeyMpn(PK,FK4) } \\
\text { - RupiahMpn } \\
\text { - KodeNtbMpn } \\
\text { - KodeNtpnMpn } \\
\text { - KodeAkunMpn } \\
\text { - P7Mpn } \\
\text { - P11Mpn }\end{array}$ \\
\hline
\end{tabular}

\subsection{Menyiapkan Database}

Tabel 1 merupakan struktur data yang digunakan untuk data warehouse dan dashboard Rekonsiliasi Penerimaan Negara

\section{$\underline{\text { Data Mart }}$}

Pembentukan data mart disesuaikan dengan kebutuhan pengguna terhadap keperluan monitoring dan laporan yang diaplikasikan dalam bentuk dashboard. Selain itu, data mart merupakan jembatan antara BI Application dengan data warehouse sehingga dashboard tidak melakukan akses langsung ke database.

\section{Antarmuka Dashboard}

Antarmuka dashboardterdiri atas sebuah halaman dashboard utama dan 5 (lima) halaman dashboard pendukung yang merupakan penjabaran dari dashboard utama.
Salah satu antarmuka dari dashboard yang dibuat adalah halaman Dashboard Utama yang menampilkan rekapitulasi hasil rekonsiliasi penerimaan negara berdasarkan kategori hasil rekonsiliasi (KPI-01), pergerakan masing-masing kategori hasil rekonsiliasi (KPI-02) dan prosentase masing-masing kategori hasil rekonsiliasi terhadap total transaksi MPN (KPI-03). Selain itu, pada halaman ini data kategori hasil rekonsiliasi dapat ditampilkan berdasarkan Bank/Pos Persepsi, Tahun, Semester dan Triwulan.

\subsection{Pengujian Sistem}

Proses pengujian meliputi validasi desain dengan menggunakan pendekatan (UED) User Experience Design dan verifikasi fungsionalitas sistem menggunakan metode fungsional BlackBox Testing.

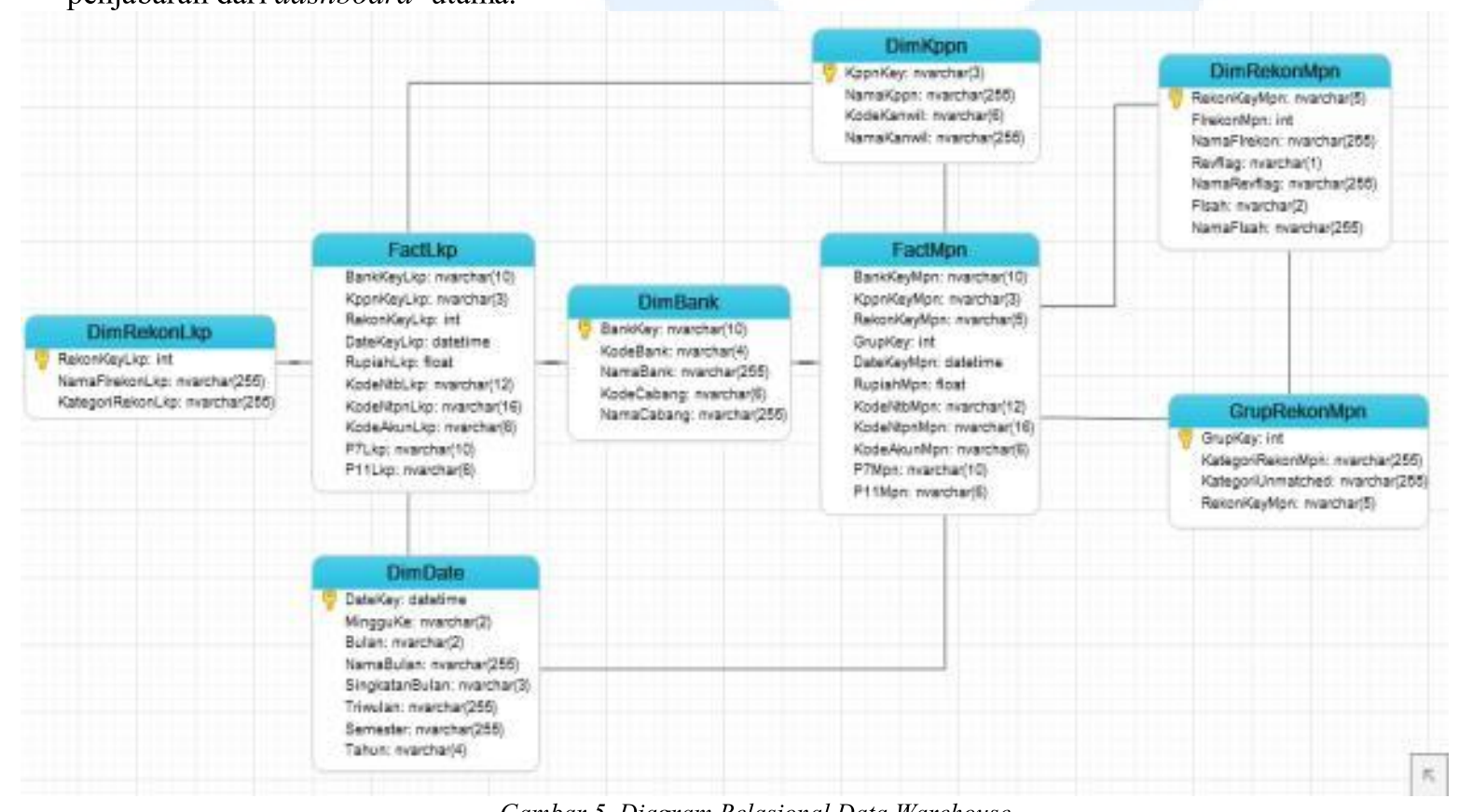

Gambar 5. Diagram Relasional Data Warehouse 

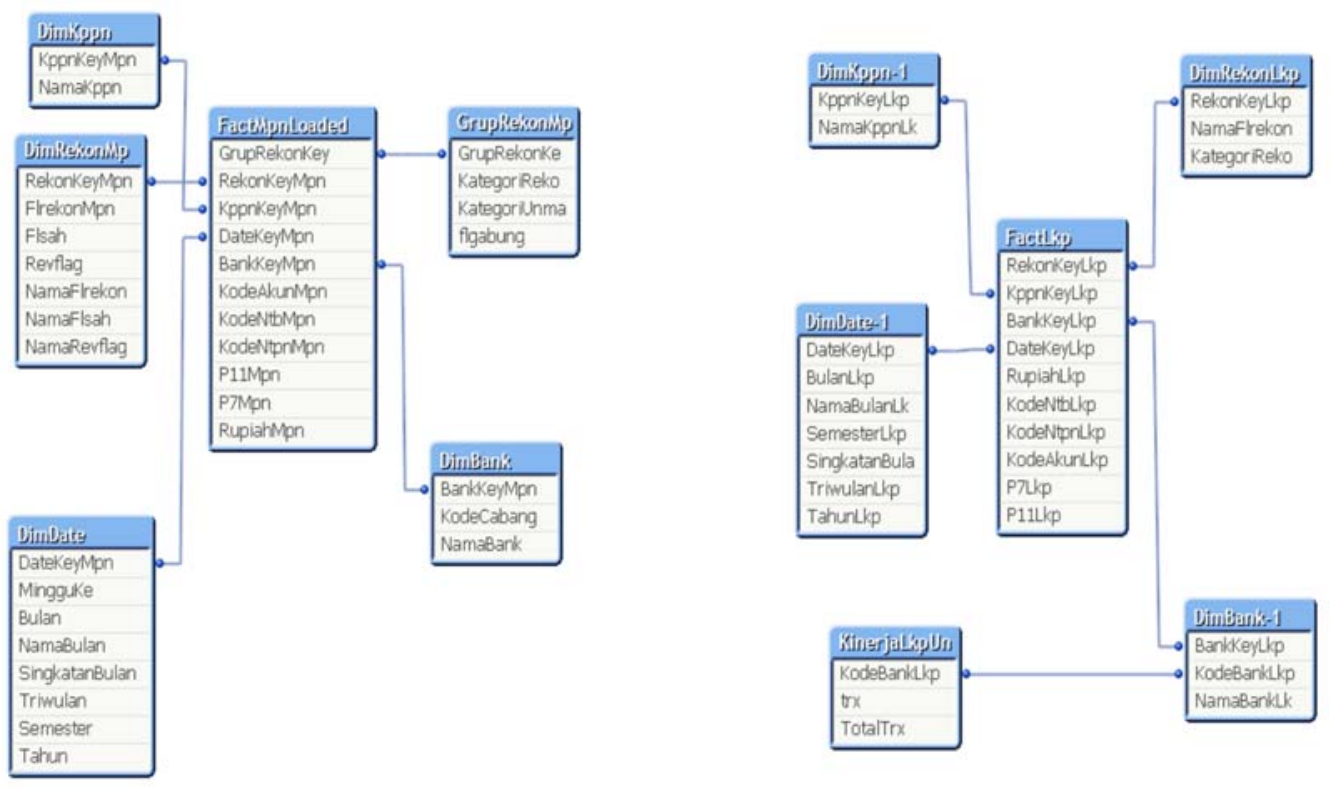

Gambar 6. Data Mart Dashboard Rekonsiliasi Penerimaan Negara

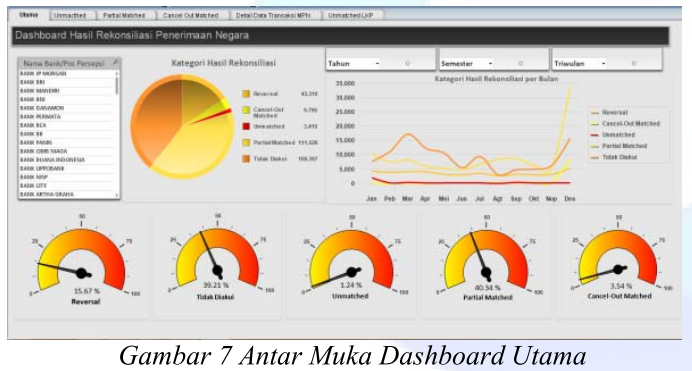

\subsection{Validasi}

Proses validasi dimulai dengan melakukan presentasi penggunaan dashboard (prototype) kepada pengguna sebagai validator. Setelah itu, validator akan mengisi daftar pernyataan yang terbagi dalam 5 (lima) kategori meliputi kategori kegunaan, aksesibilitas, kinerja, ergonomis dan desain. Validator merupakan pengguna yang dinilai merupakan pakar dan mengerti mengenai sistem yang dibangun.

Tabel 2. Validasi Desain

\begin{tabular}{llcc}
\hline No & \multicolumn{1}{c}{ Kategori/ Pernyataan } & Setuju & $\begin{array}{c}\text { Tidak } \\
\text { Setuju }\end{array}$ \\
\hline $\mathbf{A}$ & $\begin{array}{l}\text { KEGUNAAN } \\
\text { Data warehouse membantu saya dalam menyajikan data hasil rekonsiliasi } \\
\text { penerimaan negara berdasarkan dimensi tertentu }\end{array}$ & 2 & - \\
2 & $\begin{array}{l}\text { Data warehouse memudahkan saya dalam menyampaikan hasil } \\
\text { rekonsiliasi penerimann negara yang harus diklarifikasi oleh Bank/Pos }\end{array}$ & 2 & - \\
& $\begin{array}{l}\text { Persepsi } \\
\text { Dashboard membantu saya mengetahui hasil rekonsiliasi penerimaan } \\
\text { negara yang harus diklarifikasi oleh Bank/Pos Persepsi }\end{array}$ & 4 & - \\
4 & $\begin{array}{l}\text { Dashboard ini membantu saya melakukan monitoring terhadap kinerja } \\
\text { Bank/Pos Persepsi dalam melakukan pengelolaan penerimaan negara }\end{array}$ & 3 & 1 \\
5 & $\begin{array}{l}\text { Dashboard ini membantu saya mendapatkan detail transaksi hasil } \\
\text { rekonsiliasi penerimaan negara yang harus diklarifikasi oleh Bank/Pos }\end{array}$ & 4 & - \\
B & $\begin{array}{l}\text { Persepsi } \\
\text { AKSESIBILITAS }\end{array}$ & & \\
1 & $\begin{array}{l}\text { Data warehouse dapat diakses } \\
\text { Dashboard dapat saya akses }\end{array}$ & 4 & - \\
3 & $\begin{array}{l}\text { Komponen dashboard dapat termuat dengan sempurna } \\
\text { Dashboard dilengkapi dengan fitur import detail data }\end{array}$ & 4 & - \\
C & $\begin{array}{l}\text { KINERJA } \\
\text { Dashboard menghasilkan jumlah transaksi, nilai transaksi dan prosentase }\end{array}$ & 4 & - \\
2 & $\begin{array}{l}\text { sesuai dengan hasil rekonsiliasi penerimaan negara } \\
\text { Saya tidak menemukan perhitungan yang menampilkan data error pada }\end{array}$ & 4 & - \\
\hline
\end{tabular}




\begin{tabular}{lllll}
\hline D & dashboard & & \\
1 & ERGONOMIS & & \\
2 & Ukuran setiap komponen dashboard sesuai dan tidak berlebihan & 4 & - \\
& $\begin{array}{l}\text { Urutan komponen tersusun rapih dan memiliki informasi yang } \\
\text { berkesinambungan }\end{array}$ & 4 & - \\
3 & Tata letak urutan komponen konsisten & 4 & - \\
E & DESAIN & & \\
1 & Tampilan antar muka dashboard telah sesuai dengan kebutuhan & 4 & - \\
2 & $\begin{array}{l}\text { Kontras warna, ukuran, dan jenis font yang digunakan nyaman untuk } \\
\text { dilihat }\end{array}$ & 4 & - \\
\hline
\end{tabular}

Tabel 3. Hasil Verifikasi Sistem

\begin{tabular}{|c|c|c|}
\hline No & Deskripsi & $\begin{array}{c}\text { Sukses/ } \\
\text { Gagal }\end{array}$ \\
\hline 1.1 & Sunny Day - sukses menambah data KPPN & sukses \\
\hline 1.2 & Rainy Day - kolom data sumber belum termapping ke kolom DimKppn & sukses \\
\hline 2.1 & Sunny Day - sukses menambah data Bank & sukses \\
\hline 2.2 & Rainy Day - kode cabang Bank Kosong & sukses \\
\hline 2.3 & Rainy Day - mengubah desain data sumber & sukses \\
\hline 3.1 & Sunny Day - sukses menambah tanggal & sukses \\
\hline 3.2 & Rainy Day - kolom data sumber belum termapping ke kolom DimDate & sukses \\
\hline 4.1 & Sunny Day - sukses mengubah data kategori rekonsiliasi & sukses \\
\hline 4.2 & Rainy Day - kolom data sumber belum termapping ke kolom DimRekonMpn & sukses \\
\hline 4.3 & Rainy Day - kolom FLREKON tidak dikonversi & sukses \\
\hline 5.1 & Sunny Day - sukses mengubah data grup kategori rekonsiliasi Mpn & sukses \\
\hline 5.2 & Rainy Day - kolom data sumber belum termapping ke kolom GrupRekonMpn & sukses \\
\hline 5.3 & Rainy Day - kolom FLREKON tidak dikonversi & sukses \\
\hline 6.1 & Sunny Day - sukses mengubah data grup kategori rekonsiliasi LKP & sukses \\
\hline 6.2 & Rainy Day - kolom data sumber belum termapping ke kolom DimRekonLkp & sukses \\
\hline 6.3 & Rainy Day - kolom FLREKON tidak dikonversi & sukses \\
\hline 7.1 & Sunny Day - sukses menambah data transaksi MPN & sukses \\
\hline 7.2 & Rainy Day - menambahkan data dengan kolom BankKey kosong & sukses \\
\hline 7.3 & Rainy Day - mengurangi referensi tabel dimensi & sukses \\
\hline 7.4 & Rainy Day - kolom FLREKON tidak dikonversi & sukses \\
\hline 8.1 & Sunny Day - sukses menambah data transaksi LKP & sukses \\
\hline 8.2 & Rainy Day - menambahkan data dengan isian kolom tidak lengkap & sukses \\
\hline 8.3 & Rainy Day - mengurangi referensi tabel dimensi & sukses \\
\hline 8.4 & Rainy Day - kolom FLREKON tidak dikonversi & sukses \\
\hline 9.1 & Sunny Day - sukses meload data mart & sukses \\
\hline 9.2 & Rainy Day - memasukkan nama kolom yang sama & sukses \\
\hline 10.1 & Sunny Day - sukses melihat dashboard & sukses \\
\hline 10.2 & Sunny Day - menampilkan semua data & sukses \\
\hline 10.3 & Rainy Day - menampilkan data kosong & sukses \\
\hline 11.1 & Sunny Day - berhasil melihat dashboard & sukses \\
\hline 11.2 & Sunny Day - menampilkan semua data Partial Matched & sukses \\
\hline 11.3 & Rainy Day - menampilkan data kosong & sukses \\
\hline 12.1 & Sunny Day - berhasil melihat dashboard & sukses \\
\hline 12.2 & Sunny Day - menampilkan semua data Unmatched & sukses \\
\hline 12.3 & Rainy Day - menampilkan data kosong & sukses \\
\hline 13.1 & Sunny Day - berhasil melihat dashboard & sukses \\
\hline 13.2 & Sunny Day - menampilkan semua data Cancel Out Matched & sukses \\
\hline 13.3 & Rainy Day - menampilkan data kosong & sukses \\
\hline 14.1 & Sunny Day - berhasil melihat dashboard & sukses \\
\hline 14.2 & Sunny Day - menampilkan semua data Lkp Unmatched & sukses \\
\hline
\end{tabular}




\begin{tabular}{clc}
\hline No & \multicolumn{1}{c}{ Deskripsi } & $\begin{array}{c}\text { Sukses/ } \\
\text { Gagal }\end{array}$ \\
\hline 14.3 & Rainy Day - menampilkan data kosong & sukses \\
15.1 & Sunny Day - sukses melihat detail data & sukses \\
15.2 & Sunny Day - menampilkan semua data pada FactMpn & sukses \\
15.3 & Rainy Day - menampilkan tabel kosong & sukses \\
16.1 & Sunny Day - sukses menyimpan detail data transaksi MPN & sukses \\
16.2 & Rainy Day - menekan tombol cancel & sukses \\
17.1 & Sunny Day - sukses menyimpan detail data LKP Unmatched & sukses \\
17.2 & Rainy Day - menyimpan data yang telah ada sebelumnya & sukses \\
\hline
\end{tabular}

\subsection{Verifikasi}

Proses verifikasi data warehouse dan dashboard menggunakan metode fungsional BlackBox Testingyang memetakan skenario Sunny Day dan Rainy Day. terhadap masing-masing use case yang ada.

\section{SIMPULAN DAN SARAN}

Simpulan yang dapat diambil dari penelitian ini adalah penyajian informasi hasil rekonsiliasi penerimaan negara dalam mendukung monitoring atas pelaksanaan ketentuan penerimaan negara oleh Bank/Pos Persepsi membutuhkan data-data transaksi yang harus diklarifikasi oleh Bank/Pos Persepsi sesuai dengan PER-90/PB/2011. Data-data tersebut menjadi acuan dalam membangun data warehouse dan dashboard rekonsiliasi penerimaan negara.

Data warehouse penerimaan negara yang telah dibangun merupakan data OLAP yang terdiri dari tabel-tabel data KPPN, data Bank, data tanggal, data kategori rekonsiliasi MPN, data grup kategori rekonsiliasi MPN, data kategori rekonsiliasi LKP, data transaksi MPN, data transaksi LKP, dan data marthasil pemetaan dari data OLTP rekonsiliasi penerimaan negara yang dapat digunakan untuk kebutuhan analisis.

Dashboard yang telah dibangun dapat menyajikan informasi yang meliputi data reversal, data tidak diakui, data unmatched, data partial matched, data cancel out matched dan data LKP unmatchedyang harus diklarifikasi oleh Bank/Pos Persepsi secara cepat, akurat dan efektif.

Berdasarkan hasil validasi desain, dapat disimpulkan bahwa data warehouse dan dashboard telah sesuai dengan kebutuhan pengguna dalam mendukung fungsinya berdasarkan beberapa aspek berikut:

a. Kegunaan; data warehouse dan dashboard yang dapat menyajikan informasi hasil rekonsiliasi secara cepat dan akurat.

b. Aksesibilitas; data warehouse dan dashboard dapat mudah dipergunakan c. Kinerja; data warehouse dan dashboard menampilkan data hasil rekonsiliasi secara akurat.

d. Ergonomis; data warehouse dan dashboard memudahkan dalam menganalisis data hasil Rekonsiliasi Bank/Pos Persepsi sehingga dapat mempercepat proses permintaan klaririfikasi transaksi hasil rekonsiliasi penerimaan negara kepada Bank/Pos Persepsi.

e. Desain; dashboard mempunyai desain yang nyaman untuk dilihat.

Berdasarkan hasil verifikasi setiap fungsi utama yang dilakukan menggunakan skenario, data warehouse dan dashboard telah berjalan sesuai dengan desain yang telah dibuat.

\section{DAFTAR RUJUKAN}

D. P. K. Negara, Buku Panduan UAT Bank/Pos Persepsi, Jakarta: Direktorat Pengelolaan Kas Negara, 2009.

Direktorat Jenderal Perbendaharaan, "PER 90/PB/2011 tentang Rekonsiliasi Data Transaksi Penerimaan Negara pada Sistem Modul Penerimaan Negara," Jakarta, 2011.

K. K. RI, PMK-99/PMK.06/2006 tentang Modul Penerimaan Negara (MPN), Jakarta: Kementerian Keuangan RI, 2006.

K. K. RI, PMK NOMOR 37/PMK.05/2007 tentang Perubahan Kedua atas PMK NOMOR 99/PMK.06/2006, Jakarta, 2007.

D. J. Perbendaharaan, PER-NOMOR PER78/PB/2006 tentang Penatausahaan Penerimaan Negara Melalui Modul Penerimaan Negara, Jakarta, 2006.

D. J. Perbendaharaan, PER-25/PB/2012 tentang Perubahan atas PER-78/PB/2006, Jakarta, 2012.

D. Perbendaharaan, PER-90/PB/2011 tentang Rekonsiliasi Data Transaksi Penerimaan Negara BAB IV Mekanisme Tindak Lanjut Atas Data Hasil Rekonsiliasi, Jakarta, 2011.

Direktorat Jenderal Perbendaharaan, "Permasalahan dan Tindak Lanjut Penyelesaian Data MPN 2010 \& 2011," 
Sholiq, dkk., Rancang Bangun Data Warehouse dan Dashboard Rekonsiliasi Penerimaan Negara..

Direktorat Pengelolaan Kas Negara, Jakarta, 2011.

KimballGroup, The Data Warehouse Lifecycle Toolkit, 2nd Edition: Practical Techniques for Building Data Warehouse and Business Intelligence Systems.

W. Eckerson, "Performance dashboards: measuring, monitoring, and managing your business," no. Wiley and Son, Inc, 2006. http://www.qlikview.com/us/explore/produ cts/overview," [Online]. [Accessed 3112 2013].
S. A. Larissa T. Moss, Business Intelligence Roadmap - The Complete Project Lifecycle for Decision-Support Applications, 2003.

R. K. a. M. Ross, The Data Warehouse Toolkit: The Definitive Guide to Dimensional Modeling, Third Edition, Indianapolis, Indiana: John Wiley \& Sons, Inc, 2013.

J. B. \&. C. Bowles, Undercover User Experience Design, New Riders, 2010.

S. T. M. G. B.B Agrawal, Software Engineering and Testing, USA: Jones \& Bartlett Publishers, 2010. 